\title{
Assessment of the status of municipal solid waste management (MSWM) in Lucknow - Capital city of Uttar Pradesh, India
}

\author{
Archana $^{1}$, Daoud $\mathrm{Ali}^{2}$, Mohammad Yunus ${ }^{1}$ and V. Dutta ${ }^{1}$ \\ ${ }^{I}$ Department of Environmental Science, Babasaheb Bhimrao Ambedkar (A Central) University, Lucknow- \\ 226025, Uttar Pradesh, India \\ ${ }^{2}$ Department of Zoology, College of Science, King Saud University, Riyadh, 11451, Saudi Arabia
}

\begin{abstract}
Management of solid waste is one of the most challenging problems in India's cities and towns. Increasing population levels, rapid economic growth and rise in community living standards accelerate the rate of generation of municipal solid waste (MSW) in Indian cities. Most of the urban areas are currently facing a serious problem of land and water pollution due to the generation of huge quantities of solid waste and their open dumping. In the present study an assessment is made of the existing situation of municipal solid waste management (MSWM) in Lucknow city, UP (India). The current status of MSWM as per the MSW Rules, 2000 has also been appraised and an action plan for better management has been formulated. The quantitative and qualitative characteristics of MSW along with basic information have been evaluated for Lucknow city. The geographic information system has also been used to digitize the existing MSW dumping sites. The present study has showed that there are many shortcomings in the existing MSWM practices. The Lucknow city is one of the most densely populated, commercialized and urbanized city of India. This city is also adding on commercial centres and new urban extensions which are providing additional housing services and employment opportunities to increasing population resulting into generation of huge quantity of MSW. The inhabitants of Lucknow presently generate approximately 1500 tonnes of MSW every day. In the absence of sanitary landfills or other protected and lined dumping places, the MSW is transported to the various dumpsites, near fun republic mall Gomti Nagar, Telibagh Bhattha Maidan, Ghaila (Dubbga) Hardoi-Kanpur Ring Road and Ramdaskheda, Kursi Road. Such open dumping poses environmental and health hazards as leachate from open dumps are becoming major sources of groundwater contamination in the subsequent years of dumping MSW.

Keywords: Solid waste, sanitary landfills, leachate, groundwater pollution, Lucknow, Uttar Pradesh
\end{abstract}

\section{Introduction}

After China, India is the second most populated and economically growing country of the world. In future increasing population levels, rapid economic growth and rise in community living standards will significantly accelerate MSW generation rate in Indian cities. As per the Census of 2011, Lucknow city has a total population of about 4.5 million including 0.6 million floating population. Out of this about a quarter of million people are living in slums which generates about 1500 metric tonnes of municipal solid waste every day. On an average, about $60-65 \%$ of total MSW generated is collected by the municipal corporation of Lucknow, with a collection efficiency ranging from about 55 to $60 \%$. This has resulted in uncontrolled MSW generation and dumping from the municipal boundary of Lucknow city. The total quantity of MSW has been reported as 1534 Metric Ton/day and average generation at the rate of MSW $0.39 \mathrm{~kg} /$ capita/day (LNN, 2010). The annual waste generation has reported to increase in proportion of rise in population and urbanization. Issues related to disposal have become challenging as more land is needed for the ultimate disposal of these solid wastes (Idris et al., 2004). The waste pose serious hazard to human health and environment if improperly stored, treated, transported, disposed off or managed (Misra et al., 2005). Small amount of leachate can pollute large amount of groundwater posing serious health hazard due to consumption of such contaminated water (Bakare et al., 2007). In several earlier studies, it has been observed that all of the Indian cities dispose their waste in few kilometer distances from the city in open dumping places without having concept of scientific techniques of landfilling and about its impact on human health. MSWM is a major problem being faced by municipalities. It is not only a technical problem but also related with lack of awareness, political, legal, socio-cultural, environmental factors and also on available resources. . In the present study an assessment is made of the existing situation of municipal solid waste management (MSWM) in Lucknow city. The current status of MSWM as per the MSW Rules, 2000 has also been appraised and an action plan for better management has been formulated. The quantitative and qualitative characteristics of MSW along with basic information have been evaluated. The geographic information system has also been used to digitize the existing MSW dumping sites. The quantity and composition of MSW generated over last four decades, pattern of primary and secondary collection, transportation, treatment, and disposal and recycling has been discussed in detail. 


\section{Methodology}

In the first phase of the study, survey has been conducted during January 2010 to July 2012 to study twenty four MSW dumping sites and 26 depot location in Lucknow (see Fig 5). Legal aspects of MSWM in India, as well as state level provision were studied. In the second phase of the study, data were collected from LNN, Lucknow about source of MSW waste, per capita waste generation, quantity, daily disposal, processing, availability of containers and collection frequency etc. In the third phase of the study, original map of wards of Lucknow city was scanned and also digitized. Thereafter, the collected data about various depots location and MSW disposal sites has been used for the generation of maps using GIS applications.

\subsection{Legal Aspects for MSWM in India}

\section{Discussion}

For collection, segregation, storage, processing, transportation and disposal of MSW local municipal bodies are responsible according to Rules of MSW, 2000. Besides these rules, the Government of India, State Governments also drafted several acts and rules for MSWM in India. Which are summarized as follows:

i. The Water (Prevention and Control of Pollution) Act, 1974 made to consent from the state pollution control board for establishment of a sanitary landfill site and compost plant is essential and, no water pollution should be caused by the leachate that is emitted by the sanitary landfill site. The Water (Prevention and Control of Pollution) Cess Act, 1977 and amendments aspect that for MSWM there should be is provision for levying and collection of 3 Cess on water consumed for the sanitary landfilling, composting and anaerobic digesters.

ii. The Environmental (Protection) Act, 1986 aspect in regard to MSWM would be the EIA notification, 1944. For any project to be authorized an EIA report should be submitted first. Hazardous Waste (Management and Handling) Rules, 1989 and Amendment Rules, 2000 and 2003 specifies process and limits waste applicable for import and export. Occupier would be responsible for proper management and handling of waste either themselves or through the operator.

iii. The Bio- Medical Waste (Management and Handling) Rules, 1998 and Amendment Rules, 2003 recommended for treatment and disposal option according to their different 10 category. The treatment technologies would be done according to Standards given in Schedule V.

iv. The MoEF, 2000 (government of India) has been defined MSW as a waste generated from residential and commercial area in municipal area which included treated biomedical wastes may be solid or semi-solid form without including any type of hazardous industrial waste. MoEF. Municipal Solid Waste (Management and Handling) Rules, 2000 stated that every municipal authority is responsible for setting up a waste processing and disposal facility, and for preparing an annual report. The State governments will have overall responsibility for enforcement of the provisions of these rules in the metropolitan cities and within territorial limits of their jurisdiction (MSW Rules, 2000). The guidelines given in this law covers all the functional elements of municipal solid waste management. The CPCB, State Boards, NGOs and the other committees are required to monitor the compliance of the standards regarding groundwater, leachate quality, and compost quality including incineration standards, and they are to examine the proposal taking into consideration the views of other agencies. Waste collection by any method (community bin or hometo-home collection, etc.) must be conducted by using bell ringing or a musical vehicle to alert citizens without exceeding permissible noise levels.

v. The manufacturing, selling and usage of plastic bag and Non-Biodegradable garbage (control) Act has been formed in year 2006 to regulated seriously by the Cantonment (which have separate municipal body) Lucknow also prohibits throwing or deposit of these waste in open places, roads or drains in Cantt area.

\subsection{Status of MSW}

The city is in the forefront of industry with its emerging in biotechnology, having numerous small and medium-scale industries and plantations. Lucknow district covering an area of about 2528 sq. Km, encompasses the stretch ranging from $26^{\circ} 30^{\prime}$ to $27^{\circ} 10^{\prime}$ North latitude and $80^{\circ} 30^{\prime}$ to $81^{\circ} 13^{\prime}$ East longitude. Nestled on the banks of the Gomti River, Lucknow is flanked by Barabanki District on the east, Unnao on the west, Raebareli on the south and Sitapur and Hardoi districts on the north, respectively. Lucknow District population constituted 2.30 percent of total Uttar Pradesh population (Census of India, 2011). About 1,550,737 people are living in rural areas and 3,037,718 in urban areas (<http://www.censusindia.net $>$ ). Lucknow is a center of power and commercial activities and provides opportunities of employment which accelerates population so also urbanization. About 125,000 persons increase each year in urban population of the city which comes from neighboring cities for labor work, education and other job. In Lucknow the generation of waste quantity is approximately $1500 \mathrm{MT} /$ day (LNN, 2011). The city area is spread over an area of about $247.7 \mathrm{Sq} . \mathrm{km}$. The Lucknow Nagar Nigam (LNN) divided whole city is into 110 election wards (see Fig.1) and 6 zones (see Fig.5) 
for solid waste management and is responsible for collection, treatment and disposal of MSW generated in whole city.

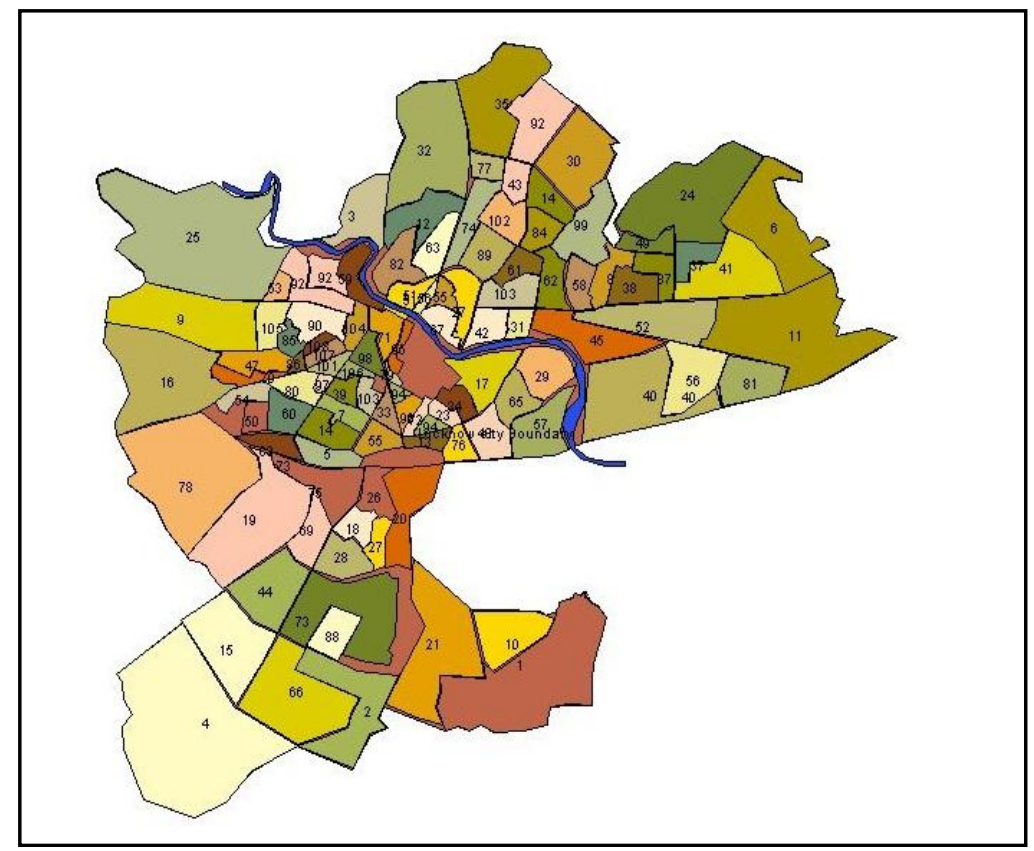

Fig.1. Arc GIS view 9.3 of outlining of 110 wards of Lucknow city (LNN, 2012)

Existing MSWM system of Lucknow does not have an engineered landfill site for disposal of waste (see Fig. 3). The Municipal Corporation of Lucknow (LMC) Cantonment Board (LCB) and Jyoti Enviro Tech are three municipal bodies responsible for MSWM in Lucknow. In the city the cleaning and collection process involves collection of MSW from the street in wheel barrows and thereafter, it is dumped into depots (see Fig. 5). MSW is then loaded into the transportation vehicles, which transport the waste to different disposal sites.

\title{
3.3. Sources and quantity of MSW
}

The Lucknow city generates approximately 1500 MT of SW daily. The organic fraction is made up of kitchen waste including food leftovers, rotten fruits, vegetables, leaves, crop residues, animal excreta and bones. Plastics, glass, metals, and paper account for less than 15 percent of the total waste. In low income households, solid waste is stored in open baskets and any available cans which do not meet hygienic standards. Component of MSW founded to be bio-degradable, non-biodegradable (plastic, glass and metal etc.), Inert material (bricks, stones and ashes etc.) indicates the construction and demolishes activities in the city. The amount and components of solid waste generated in this city varies with income levels (see Table.1.).

\section{Percentage of Total Waste}

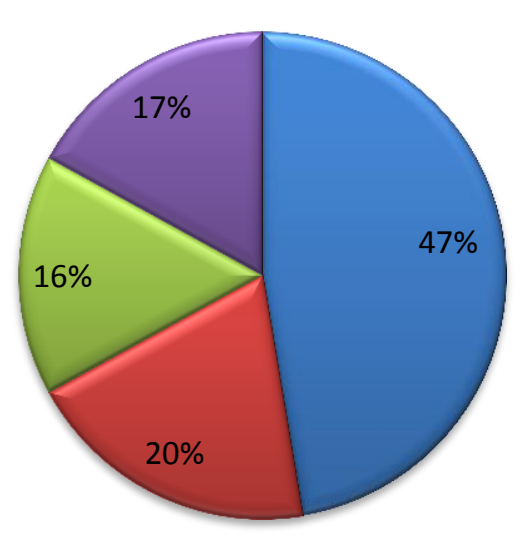

\author{
D Organic matter \\ Mixed waste \& drain silt \& \\ street sweeping \\ $\square$ Construction debris \\ $\square$ Recyclables \\ (paper,rubber, synthetics, \\ glass \& metals etc)
}

Fig 2: Composition of Municipal Solid Waste in the Lucknow (U P Jal Nigam, Lucknow, 2010) Table 1: Per capita waste generation in Lucknow 


\begin{tabular}{|l|l|l|}
\hline Categories & $\begin{array}{l}\text { Approx percapita waste generation } \\
\text { (g/day) }\end{array}$ & $\begin{array}{l}\text { Waste } \\
\text { generation } \\
\text { (in \%) }\end{array}$ \\
\hline Low income group & 172.89 & 27 \\
\hline Middle income group & 162.67 & 32 \\
\hline High income group & 221.21 & 40 \\
\hline
\end{tabular}

Source: LNN, 2011 and UP Jal Nigam, 2009

This is the fact that low income groups generate less waste per capita than middle and high income groups. The specific waste generation rate in low income areas is low at $172.89 \mathrm{~g}$ per capita per day. Middle income areas show a specific waste generation rate of $162.67 \mathrm{~g}$ per capita per day and high income residential areas range with 221.21g per capita per day. Packaged products and empty cans form a significant part of the waste in high income areas. In many low income areas people dump waste in unauthorized places where cattel founded eating food material (see Fig 4). Substantial amount of waste are dumped into canals and drains.

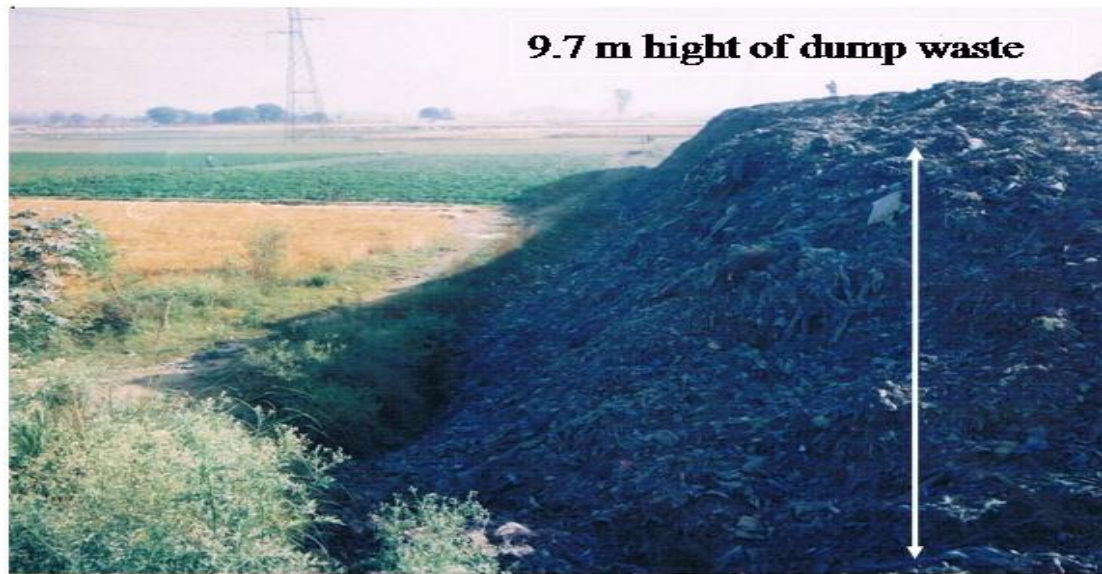

Fig 3: Showing about $10 \mathrm{~m}$ height of dumped MSW in Jehta Mor Bandha

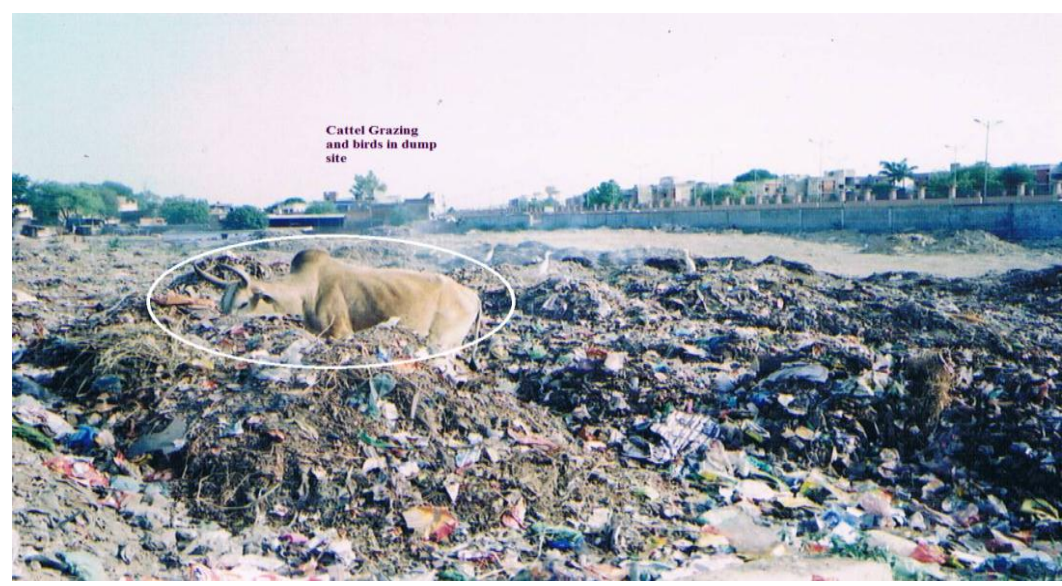

Fig 4: Showing cattle grazing and birds in open dump site of Telibagh

\subsection{Primary collection of MSW}

The municipalities and NGO's related with municipalities are responsible for collection of segregated waste from door-to-door (DTD) according to MSW Rules, 2000. NGOs (Jyoti Enviro Tech Limited) participate in the (DTD) system which is currently collecting solid waste in 51 wards of Lucknow. MSW collection is partially collected. It is segregation by rag pickers at community bin and landfill. Sweepers collect the MSW from the roads/streets and carry it to the nearest collection points (depots or community bins). MSW produced from individual households is taken to the collection point or deposited on the adjacent roadside from where it is collected when the roads are being swept. The handcart of six bucket collected waste and transported to the municipal bins which is designed especially for segregation of recyclable and non-recyclable wastes. According to Singh, (2011) this collection would be extended to remaining 59 wards in next six months when the processing plant would be ready. 


\subsection{Methods of storage of MSW}

LNN have provided twenty nine depots for the temporary storage of MSW, which are scattered throughout the city (see Table.2. and Fig. 5). The depots are an open space enclosed on three sides with a masonry wall of about 3.5 to $4.35 \mathrm{~m}$ height, with capacities ranging from 15 to $40 \mathrm{~m} 3$ and located in a congested area containing narrow winding streets. These depots are in good condition. Although waste is scattered toward the road and animals also founded there in search of food.

\subsection{Secondary collection of MSW}

In Lucknow city the disposal sites are generally within and also out of LNN area. The MSW is directly collected from the collection points by the collection vehicle to the disposal site. Since the MSW is collected again from the collection points to the disposal site, it is termed secondary collection. The hauled container, stationary container, manually loaded dumper and mechanically loaded dumper systems are used during secondary collection, transportation and disposal of MSW.

\subsection{Transportation of MSW}

MSW is transported by their own vehicle; private vehicles are not being used. This vehicle uses good covering on the waste to prevent odourlessness and flying of waste during transportation. LNN have a large number of vehicles for transportation. Presently LNN uses 3 hywa, 23 dumpers placer, 6 tractors, 44 trucks, 16 Tata-207, 68 Chota Haathi, 3 Refuse 8 collectors and 39 Vikram etc. vehicles for collection and transportation of the waste from primary and secondary waste collection point to the landfills.

\subsection{Processing of MSW}

MSW is being processing in several ways in LMC area.

\subsubsection{Composting}

Currently MSW management system has no facility of composting. In the cattle colony near River Gomti where cattels produces dung has not been collected by the LNN workers. So the people are living in unhygienic condition. Mosquito, rodents and flies population increases to cause several diseases in these areas. Gobar also reaches to the river stream on flooding in the rainy season from June to September and in January month.

\subsubsection{Incineration}

This equipment is only used for hospital waste. Approximately $500 \mathrm{Kg}$ waste is incinerated per day in the hospital. Rest of the waste is dumped in nearby open dumping places (LNN, 2010). Clinic dumps their waste in open dump which is collected by LNN.

\subsubsection{Recycling}

Recyclable waste including paper, card board, plastics, polythene, glass, metals, rubber, leather and textiles etc. collected and segregated by waste pickers and collectors. This collected waste daily collected and transferred to dealers who are living in slums near their residence. The waste collector and waste picker are generally illiterate and working without safety equipment such as boots and gloves although they contribute to the environment.

\subsubsection{Energy Generation}

In Ghaila, on Hardoi, Sitapur Road an electricity generation plant has been established. But started without having any proper management plan. So it stopped before electricity generation and without giving any output. At present there is no electricity generation from MSW.

\subsection{Disposal of MSW and analysis of landfill site in India}

MSW is generally disposed in the nearby low-lying area; pond, river, lake and wasteland in the urban area in uncontrolled manner without application of daily cover material. This is the reason of abate odour and attraction of birds, animals and rodents so decrease site litter. Selection of these landfill sites by LNN depend only on availability, not on scientific and socio-environmental criteria of landfill. There are many open disposal sites where the MSW of the city is being disposed off. Since 1980, many landfills have been created in Lucknow. At present, six landfill sites are active, namely Dubagga, Jehta Mor bundha, RR Bhawan, Daliganj Pul (near Mankameshwar Mandir Marg), Tile Wali Masjid and Telibagh Bhatha Maidan which covers over total area of about 260729.4 square meter (see Table 2 and Fig. 5). 
Table 2: Position of Active And Closed MSW Dumping sites

\begin{tabular}{|c|c|c|c|c|}
\hline Site no. & Site name & $\begin{array}{l}\text { Dumping starts } \\
\text { from }\end{array}$ & Tot Area in sq.m & $\begin{array}{l}\text { Position of } \\
\text { site }\end{array}$ \\
\hline 1 & $\begin{array}{l}\text { Dubagga, } \\
\text { Kadimi Kbristan }\end{array}$ & 2007 & 61420.0803 & Active \\
\hline 2 & Jehta-Mor Bandha & 2007 & $23660.5909,17843.6384$ & Active \\
\hline 3 & Yadav Chowraha & 2007 & $0359.7415,580.5386,3559.5252$ & Closed \\
\hline 4 & Pulton Chawni & 2000 & 8498.7929 & Closed \\
\hline 5 & Aliganj Sec-Q & 2000 & 100441.9699 & Closed \\
\hline 6 & Near Aliganj Sec-Q & 2000 & 58329.5822 & Closed \\
\hline 7 & RR Bhawan & 2010 & $91466.5592,8459.2445$ & Active \\
\hline 8 & Near Race cource Maidan & 2009 & 63768.1939 & Closed \\
\hline 9 & Near Telibagh & 2007 & 3112.4341 & Closed \\
\hline 10 & Telibagh Main Bhattha Maidan & 2007 & 46904.1049 & Active \\
\hline 11 & $\begin{array}{l}\text { Rashmi Khand, Near Kansiram } \\
\text { Smriti }\end{array}$ & & 37741.0768 & Closed \\
\hline 12 & Near Nahar Chowraha & 2007 & 16667.2014 & Closed \\
\hline 13 & Ramdas Khera & 2006 & 23468.9528 & Closed \\
\hline 14 & Chunnu Khera Village & 2006 & 6174.3185 & Closed \\
\hline 15 & Hansa Khera & 2007 & 1697.0575 & Closed \\
\hline 16 & Near Budheshvr Chowraha & 2006 & 21051.5585 & Closed \\
\hline 17 & $\begin{array}{l}\text { Bohar Village, Near Alamngr } \\
\text { Rlyline }\end{array}$ & 2008 & 2729.3947 & Closed \\
\hline 18 & Moti Jheel in Aishbag & - & 45061.3717 & Closed \\
\hline 19 & Budha Park & - & 40552.9199 & Closed \\
\hline 21 & Hathi Park & & 13566.9459 & Closed \\
\hline 22 & $\begin{array}{l}\text { Daliganj pul, Mankameshwar } \\
\text { Mandir Marg }\end{array}$ & & 5194.4264 & Active \\
\hline 23 & Tile Wali Masjid & 2007 & 5780.7858 & Active \\
\hline 24 & Gandhi Setu & 2007 & 38535.7156 & Closed \\
\hline
\end{tabular}

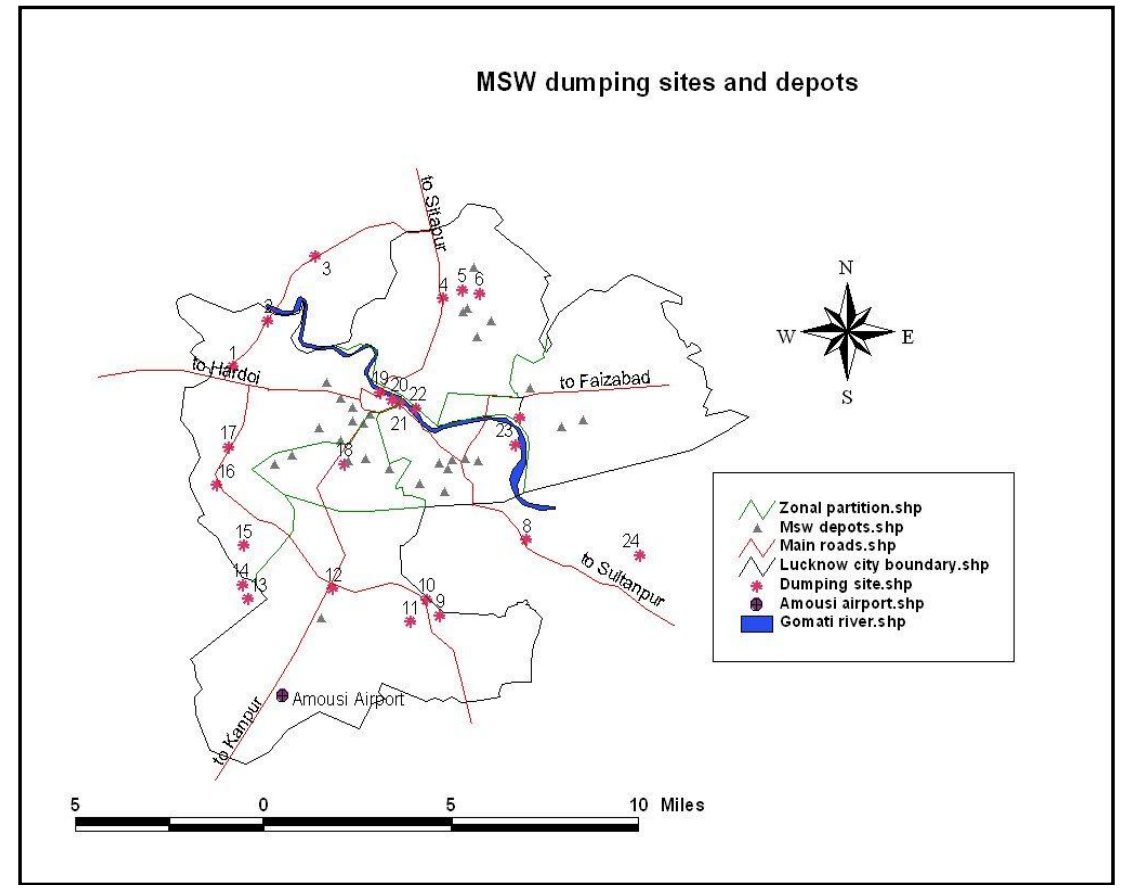

Fig 5: Arc GIS view 9.3 map showing MSW dumping sites and collection depots in Lucknow city 
Waste releases from household, industry, commercial, medical, and slaughter houses are disposed together. The dumped waste then leveled and compressed with hydraulic bulldozers. Construction and demolishes waste and inert material are used as covering material in Telibagh Bhatha Maidan. Soil covering as a covering material Lucknow Cantonment area at Sultanpur Road. It comes under Cant Municipal Corporation which is only responsible for collection to dumping of waste from Cant area only. In the city landfills are devoid of base liner or leachate collection, treatment and scientific disposal system according to MSWM Rules, 2000. Therefore leachate when generates from the landfill which is either closed or open percolate to the groundwater or mixes with nearby surface water or flows toward low lying areas specially during rainy season. Various studies conducted by Mor et al (2006); Kumar et al (2002) and Kumar and Alapp (2003) founded and proved that groundwater of residential area near the landfills significantly contaminated by leachate which is a combination of liquid residues of heavy and toxic metals. The physical appearance of leachate when it emerges from a typical landfill site is a strongly odored black colored liquid which severely contaminated groundwater aquifers. Meanwhile, residents of Dubagga, Telibag bhattha maidan and Jehta Mor Bandha are unhappy.

\section{Initiatives and technology towards improvement of MSW}

LMC proposed Master Plan (MP) for the treatment and disposal of MSW for the period of 2005-2021. The objective of the MP is to implement their recommend measures for improvement in the treatment and disposal of MSW through public and private partnership. On other hand Indian Express, Lucknow in 2011 published news that the state government has selected project of Jyoti Enviro Tech Private Limited (NGO) under Jawaharlal Nehru National Urban Renewal Mission (JNNURM). The plant is coming up in Shivri village on Mohan Road. The agreement has been signed for door-to-door collection of solid waste, its treatment in processing plant and disposal at a landfill site for next 30 years. The municipal solid waste processing plant and the garbage disposal site currently being developed on a 19-hectare land in Lucknow which will have the capacity to treat city waste only for five years. Source segregation started with cooperation of LNN, NGO and private collectors although waste mixes again in primary collection point. These wastes collector of NGO has been provided aprons. Poor people have a lower willingness to pay for environmental quality, due to unawareness about pollution, illiteracy and income elasticity of LNN, s environmental services. Only 31 percent, out of about 82 percent of the population that relied on communal waste disposal sites, paid a levy (Benneh et al., 1993).

\section{Conclusion and Recommendation}

The study concludes that the present policy and infrastructure are inadequate in dealing with the enormous quantity of MSW generated in the city. MSWM of this city is unsatisfactory and thereby needs immediate attention. Increase in quantities of MSW due to rapid urbanization, commercialization and inability of providing daily collection service cause nuisance and health hazards. The waste management plan also needs significant cooperation of public in source segregation from the residential sectors. The intervention is needed not only in policy formation, but also active involvement in waste collection and transportation till the waste is dumped in the sanitary landfill sites for implementation of waste management policy. For this, media can play a significant role and aware citizens calling for their active involvement. Informal collectors including waste pickers, waste recyclers, scavengers and waste carriers must be fully integrated into the waste management stream in order to realize the benefits of their contributions to environmental management in the city. Jyoti Enviro Tech Private Ltd. (NGO) had took a big step towards improving MSWM practices by privatizing the collection and transportation of MSW. This NGO started door- to-door collection of segregated waste in certain wards of the city. This segregated waste should be taken to the designated dumping sites after careful recycling and composting. The segregation of waste at source and promotion of recycling or reuse would reduce the quantity of waste and the burden on landfills and would provide raw materials for manufacturers. Biodegradables should be processed by composting and anaerobic digestion. Landfilling should be restricted to those wastes that are non-biodegradable or inert or which are not suitable for recycling. The study presents the current scenario of MSWM, which will be helpful in creating awareness among the people and the planners. The MSWM data obtained from Arc GIS maps are responsible for the retrieval, update and visualization of the information required. The produced maps with data can provide LNN, environmental engineers and decision makers about the present MSWM system, which is required for the improvement of the existing system and for future planning. NGO and LNN should collect cattle dung from cattle shelters/colonies of the whole city. In the cattle colony, LNN should provide gobar gas plant to the people who are living in unhygienic condition. The dung also reaches the river stream due to flooding in the rainy season from June to September and in January month. The dung if collected by the LNN can produce lots of organic fertilizer if supply in the rural area could be arranged. Biomedical and industrial wastes must not be mixed with MSW. Municipal authorities are to establish and maintain MSW storage facilities that do not create unhygienic and unsanitary conditions in the 
area. Citizens must be encouraged by the municipal authority to segregate wastes. Vehicles during waste transportation must be covered and the MSW must be processed in such as way which could reduce burden on landfills. Finally, it is clear that availability of such data would be helpful in the selection of appropriate technology for solid waste management in Lucknow. In year 2021 the situation may reach critical proportion. Specifications for maintenance of landfill sites and various other processing techniques should be applied such as composting; leachate treatment and incineration as given in the MSW Rules, 2000. LNN and other urban local bodies Uttar Pradesh should take up the issue of MSWM on priority and show their collective responsibility and seriousness for proper disposal and treatment of MSW for the entire Lucknow city.

\section{Acknowledgements}

The authors acknowledge BBAU, Lucknow in facilitating and supporting the study. The authors also acknowledge the contribution rendered by the official and technical staff of LNN, Lucknow for completing this study.

\section{References}

[1]. A. Adeolu, O. Ada, A. Gbenga, and O. Adebayo, Assessment of groundwater contamination by leachate near a municipal solid waste landfill. African Journal of Environmental Science and Technology 5 (11), 2011, 933-940

[2]. Agriculture management center, Impact evaluation report of Baldirai watershed, Sultanpur Distt in U.P. Indian Instt of Management, Lucknow. 2002

[3]. P. A. Asnani, Report on Solid Waste Management India Infrastructure. 2006

[4]. A. A. Bakare, A. K. Pandey, M. Bajpayee, D. Bhargav, D. K. Chowdhuri, K. P. Singh, R. C. Murthy and A. Dhawan, DNA Damage Induced in Human Peripheral Blood Lymphocytes by Industrial Solid Waste and Municipal Slidge Leachate. Environmental and Molicular Mutagenesis 48, 2007, 30-37

[5]. G. Benneh, J. Songsore, J. S. Nabila, A. T. Amuzu, K. A. Tutu, Y. Yangyuoru and G. McGranahan, Environmental Problems and the Urban Household in the Greater Accra Metropolitan Area (GAMA) Ghana, Stockholm Environment Institute, Stockholm, Sweden. 1993

[6]. K. O. Boadi and M. Kuitunen, Municipal Solid Waste Management in the Accra Metropolitan Area, Ghana. The Environmentalist, 23, 2003, 211-218

[7]. BIS, Bureau of Indian Standard Draft, ( Indian Standard Drinking Water Specification (Second Revision of IS 10500, 2009) CA 4

[8]. Census of India, Ministry of Home Affairs, Government of India (GoI). <http://www.censusindia.net>,2001

[9]. Census of India, Ministry of Home Affairs, Government of India (GoI). <http://www.censusindia.net>,2001

[10]. S. Chattopadhyay, A. Dutta and S. Ray, Municipal solid waste management in Kolkata, India. A review. Waste Management, 29 (4),2009, 1449-1458

[11]. CPHEEO, (Central Public Health Environmental Engineering Organisation, 2000)

[12]. ENVIS, Urban Municipal Waste Management Newsletter (Sponsored by: Ministry of Environment and Forests, Government of India, New Delhi) National Solid Waste Association of India, www.nswai.com, 14, 2009,1-9

[13]. S. Esakku, A. Swaminathan, O. P. Karhtikeyan, J. Kurian and U. K. Palanivelu, Municipal solid waste management in Chennai city, India. Sardinia , 10 th International Waste Management and Landfill Symposium CISA, Environmental Sanitary Engineering Centre, Italy, 2007

[14]. Express News Service, 25 hectares more needed for extension of waste processing plant. Indian Express, 3 June, 2011

[15]. Govt of UP, Lucknow City Development Plan. (S Feedback Ventures Pvt. Ltd. 2006) 18-32

[16]. GWB, Ground Water Scenario in Major Cities of India. (Central Ground Water Board, Ministry of Water Resources, Government of India,2011) www.cgwb.gov.in, www.mowr.gov.in

[17]. A. Idris, B. Inane, M. N. Hassan Overview of waste disposal and landfills/dumps in Asian countries. Material Cycles and Waste Management, 16, 2004, 104-110.

[18]. D. Kumar and B. J. Alappat, Analysis of Leachate Contamination Potential of a Municipal Landfill using Leachate Pollution Index. Workshop on Sustainable Landfill Management Chennai, India, 2003, 147-153

[19]. S. Kumar, Municipal Solid Waste Management in India: Present Practices and Future Challange. 2005 Sunil neeri@ yahoo.co.in

[20]. S. Kumar, J. K. Bhattacharyya, A. N. Vaidya, T. Chakrabarti, S. Devotta and A. B. Akolkar Assessment of the status of municipal solid waste management in metro cities, state capitals, class I cities, and class II towns in India: An insight. Waste Management 29, 2009, 883-895

[21]. D. J. Lisk, Environmental effects of landfills. The Science of The Total Environment, 100, 1991, 415-468

[22]. LMC, Lucknow Municipal Corporation, Lucknow Nagar Nigam, Uttar Pradesh, India, Unpublished data, 2011

[23]. M. A. Memon, Integrated solid waste management based on the 3R approach. J Waste Manag 12, 2010, 30-40

[24]. V. Misra and S. D. Pandey, Hazardous waste impact on health and environment for development of better waste management strategies in future in India. Environment International 31, 2007, 417-431

[25]. MoEF, Ministry of Environment and Forests Notification, New Delhi. 2000

[26]. S. Mor, K. Ravindra, R. P. Dahiya and A. Chandra, Leachate Characterization and Assessment of Groundwater Pollution Near Municipal Solid Waste Landfill Site. Environmental Monitoring and Assessment 118 (1-3), 2006, 435-456

[27]. K. Owusuboadi and M. Kuitunen, Municipal Solid Waste Management in the Accra Metropolitan Area, Ghana. The Environmentalist 23, 2003, 211-218,

[28]. H.A. Qdais, Techno-economic assessment of municipal solid waste management in Jordan. Waste Management 27(11), 2007, $1666-72$

[30]. N. Rajkumar, T. Subramani and L. Elango, Groundwater Contamination Due to Municipal Solid Waste Disposal. A GIS Based Study in Erode City. International Journal of Environmental Sciences 1(1), 2010, 39-46

[31]. T. V. Ramachandra, Integrated Management of Municipal Solid Waste. Environmental Security : Human \& Animal Health, 2007, 265-286 cestvr@ces.iisc.ernet.in

[32]. T. V. Ramachandra and S. Bachamanda, Environmental audit of Municipal Solid Waste Management. Environmental Technology and Management, 7, 2007, 369-392 
[33]. P. R. Schroeder, Contaminant Pathways Evaluations for up Upland Confined Placement: Leachate and Volatilization. Dredged Material Assessment and Management Seminar Sacramento, CA, 2008, 1-32

[34]. P. K. Srivastava, K. Kulshreshtha, C. S. Mohanty, P. Pushpangadan and A. Singh, Stakeholder-based SWOT analysis for successful municipal solid waste management in Lucknow, India. Waste Management 25, 2005, 531-537

[35]. The Gazette of India, 2000, Part II, Section 3, Subsection (ii), No. 648,

[36]. U. Isalkar, Health hazard from black toxic liquid oozing out of piles of garbage at Urali Devachi-Phursungi. The Times of India Pune, August 4, 2011

[37]. USEPA, Municipal Solid Waste Generation, Recycling and Disposal in the United States: Facts and Figures, United States Environmental Protection Agency EPA-530-F-08-018, 12, 2008

[38]. P. Vasanthi, S. Kaliappan and R. Srinivasraghvan, Impact of poor solid waste management on ground water. Environmental Monitoring and Assessment 143, 2008, 1-3 